\title{
Pneumococcal meningitis-associated bihemispherical acute vasculitic infarcts
}

\author{
Vikram Khardenavis, ${ }^{1}$ Sharvari Kulkarni, ${ }^{2}$ Anirudda Deshpande ${ }^{3}$
}

${ }^{1}$ Department of Medicine, Miraj Medical College, Miraj, India ${ }^{2}$ Maharashtra Institute of Medical Education and Research, Pune, India ${ }^{3}$ Department of Neurology, Vinayaka Neuro Multispecialty Clinic, Warangal, India

\section{Correspondence to} Anirudda Deshpande, dr.anirudda.deshpande@gmail. com

Accepted 20 June 2017

\section{CrossMark}

To cite: Khardenavis $V$ Kulkarni S, Deshpande A. BMJ Case Rep Published Online First: [please include Day Month Year]. doi:10.1136/ bcr-2017-221328

\section{DESCRIPTION}

A 23-year-old woman with no premorbid illness presented with features of high-grade fever since 3 days. She developed progressively deteriorating sensorium, recurrent vomiting and multiple episodes of generalised tonic clonic seizures. On examination, funduscopy was normal. The patient was drowsy but arousable, disoriented to person or place. She had neck stiffness. Kernig's sign was positive. She did not localise the central (sternal) deep painful stimuli briskly with either hand although the definite paucity of any limb could not be made out. Considering the short clinical history with a triad of fever, altered sensorium and seizures and associated signs of meningeal irritation, clinical diagnosis of bacterial or viral meningoencephalitis was thought of. MRI brain showed bihemispherical multiple cortical-subcortical lacunar infarcts (figure 1). MRI contrast images did not show any significant meningeal enhancement. With the strong suspicion of meningoencephalitis, cerebrospinal fluid (CSF) analysis was done after the imaging of the brain. It showed very low sugars, normal proteins, over 300 cells with neutrophil predominance and low CSF/blood glucose index, suggestive of bacterial meningoencephalitis. The CSF culture confirmed pneumococcal growth. However, blood culture was sterile at 48 hours probably since intravenous ceftriaxone was initiated before the blood sample was collected. The patient improved with injectable vancomycin and ceftriaxone for 2 weeks, along with injectable dexamethasone which was tapered and stopped in 3 days.

Pneumococcal infection is probably the most common bacterial meningitis associated with acute cerebrovascular accidents due to the inflammation induced through bacterial bloodstream invasion

\section{Learning points}

- Pneumococcal meningitis can often lead to vasculitis, causing cerebrovascular accidents, commonly in the form of infarcts and rarely intracerebral bleeds.

- This commonly occurs in elderly population and very rarely in young adults.

- Intravenous steroids in the cover of antibiotics, as per culture and sensitivity pattern are the treatment of choice.
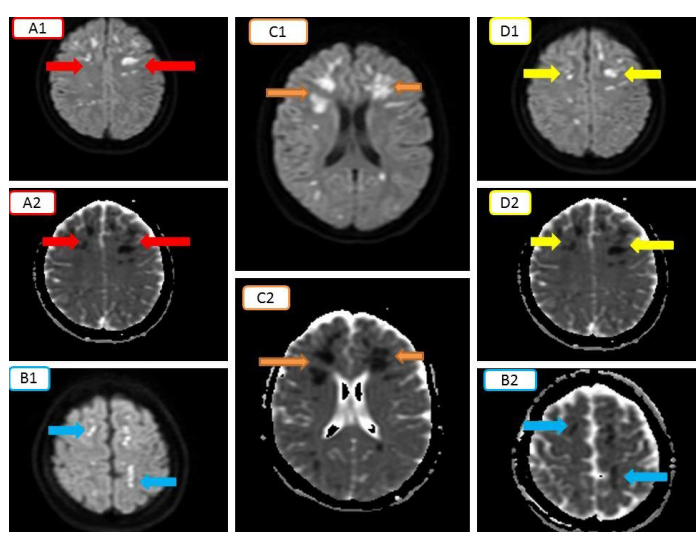

Figure 1 (Collage) DWI and corresponding ADC. Multiple areas of corresponding diffusion restriction suggestive of acute infarcts (A1-A2, B1-B2, C1-C2, D1D2). ADC, apparent diffusion coefficient; DWI, diffusionweighted images.

and activation of the complement and coagulation systems. ${ }^{1}$ Ischaemic cerebrovascular accident (CVA) is more common as compared with haemorrhagic. Elderly individuals are more commonly affected. ${ }^{2}$ It is a rarity to have a young 23-year-old woman manifest as described above. Also, other cases with cerebral vasculitis in pneumococcal meningitis have occurred late in course of admission or around discharge. ${ }^{3}$

Contributors VK and SK: made substantial contributions to the conception and design of the work, acquisition, analysis and interpretation of the data. AD: involved in drafting the work and revising it critically for important intellectual content.

Competing interests None declared.

Patient consent Obtained.

Provenance and peer review Not commissioned; externally peer reviewed.

(C) BMJ Publishing Group Ltd (unless otherwise stated in the text of the article) 2017. All rights reserved. No commercial use is permitted unless otherwise expressly granted.

\section{REFERENCES}

1 Mook-Kanamori BB, Geldhoff M, van der Poll T, et al. Pathogenesis and pathophysiology of pneumococcal meningitis. Clin Microbiol Rev 2011;24:557-91.

2 Bodilsen J, Dalager-Pedersen M, Schønheyder HC, et al. Stroke in community-acquired bacterial meningitis: a danish population-based study. Int J Infect Dis 2014;20:18-22. ISSN 1201-9712.

3 Klein M, Koedel U, Pfefferkorn T, et al. Arterial cerebrovascular complications in 94 adults with acute bacterial meningitis. Crit Care 2011;15:R281 
Copyright 2017 BMJ Publishing Group. All rights reserved. For permission to reuse any of this content visit http://group.bmj.com/group/rights-licensing/permissions.

BMJ Case Report Fellows may re-use this article for personal use and teaching without any further permission.

Become a Fellow of BMJ Case Reports today and you can:

- Submit as many cases as you like

- Enjoy fast sympathetic peer review and rapid publication of accepted articles

Access all the published articles

- Re-use any of the published material for personal use and teaching without further permission

For information on Institutional Fellowships contact consortiasales@bmjgroup.com

Visit casereports.bmj.com for more articles like this and to become a Fellow 